\title{
SOIL AND WATER MICROORGANISM DIVERSITY OF MANGROVE FOREST OF TELUK KELUMPANG, SELAT LAUT AND SELAT SEBUKU NATURAL RESERVE
}

\author{
Wawan Halwany* and Susy Andriani \\ Banjarbaru Forestry Research Institute \\ Jl. A. Yani Km 28,7 Guntung Manggis, Landasan Ulin, Banjarbaru, South Kalimantan, Indonesia
}

Received: 23 October 2013, Revised: 31 August 2015, Accepted: 7 September 2015

SOIL AND WATER MICROORGANISM DIVERSITY OF MANGROVE FOREST OF TELUK KELUMPANG, SELAT LAUT AND SELAT SEBUKU NATURAL RESERVE. Mangrove is a unique ecosystem that has complex biotic and abiotic components. Soil and water microorganisms have function as decomposer in mangrove forest ecosystem. This paper studies the soil and water microorganisms' diversity, their potential, function in ecosystem and their role as environmental parameters in mangrove area of Teluk Kelumpang, Selat Laut and Selat Sebuku Natural Reserve (Kelautku Natural Reserve). Data of soil and water microorganisms were recorded from soil and water samplings then analyzed in the laboratory. Results show that benthos in Selat Sebuku figure the highest diversity index. Anadara granosa is one of the common benthos found in Selat Sebuku. In contrary the phytoplankton in Selat Sebuku is the lowest value compared to the other two locations, due to the settlements in the locations and it was suspected that Selat Sebuku has a relatively larger wave exposure than the two other locations. In addition, input of organic matters from the settlements in Teluk Kelumpang and Selat Laut is also effected by the growth of phytoplankton. Cyanophyta found in Teluk Kelumpang and Selat Laut was genera of Oscillatoria that showed high tolerance genera to the environment conditions.

Keywords: Diversity, soil and water microorganism, mangrove forest, Kelautku Natural Reserve

KEANEKARAGAMAN MIKROORGANISME TANAH DAN AIR HUTAN MANGROVE CAGAR ALAM TELUK KELUMPANG, SELAT LAUT DAN SELAT SEBUKU. Mangrove adalah suatu ekosistem unik yang memiliki komponen biotik dan abiotik yang komplek. Komponen mikroorganisme tanah dan air berfungsi sebagai dekomposer dalam ekosistem mangrove. Tulisan ini mempelajari keanekaragaman mikroorganisme tanah dan air, potensi dan fungsinya dalam ekosistem, dan parameter lingkungan di kawasan mangrove Cagar Alam Teluk Kelumpang, Selat Laut, dan Selat Sebuku (Cagar Alam Kelautku). Data mikroorganisme tanah dan air diambil dengan cara pengambilan contoh uji tanah dan air kemudian dianalisis di laboratorium. Hasilpenelitian menunjuk.kan bahwa Selat Sebuku memiliki indeks keanekaragaman benthos tertinggi. Salah satu kelimpahan bentosyang banyak ditemukan di Selat Sebuku adalah Anadara granosa. Berlawanan dengan kelimpahan benthos kelimpahan plankton terendah di Selat Sebuku. Hal ini diduga gelombang laut lebih besar di Selat Sebuku dan kepadatan pemukiman lebih banyak di Teluk. Kelumpang dan Selat Laut yang menyebabkan adanya input dari limbah rumah tangga ke dalam perairan sekitarnya. Cyanophyta yang hanya ditemukan di Teluk. Kelumpang dan Selat Laut merupakan genera Oscillatoria yang menunjukkan toleransi tinggi terhadap kondisi perairan

Kata kunci: Keanekaragaman, mikroorganisme tanah dan air, hutan mangrove, Cagar Alam Kelautku

*Corresponding author: wawanh73@gmail.com 


\section{INTRODUCTION}

Mangrove forest gives huge benefits to human life and produce economic services. Mangrove functions as coastline protection, food chains support, and carbon sequestration (Giesen, Wulffraat, Zieren, \& Scholtren, 2006). Mangrove leaves are the biggest parts of the primary litter products and provide food for the consumers and contribute to the food chains in coastal areas by the fallen litter of the leaves (Ananda, Sridhar, Raviraja, \& Barlocher, 2007). While the economic functions are many, e.g. to produce construction timber, industrial raw materials, firewood and charcoal, honey, and to support the breeding and cultivation of fish, milkfish, shrimp, clams, crabs, and also as a tourism object.

Domingues, Barbosam, \& Galvao (2008) stated that some important ecological functions of Phytoplankton were as primary producer that directly and indirectly fuels the food webs, produce important impacts on water quality (e.g. by affecting turbidity and concentration of dissolved oxygen) and plays a number of other major roles in many ecosystem processes. In consequence, phytoplankton is usually employed as an indicator of change in nutrient loads and as a key element for assessing eutrophication in marine systems. The phytoplankton diversity is indirectly affected by temperature in the post-bloom phase through changing zooplankton composition and grazing activities (Lewandowska, Hilldebrand, Lengfellner, \& Sommer, 2014)

South Kalimantan has mangrove forest conservation areas which are classified as a nature reserve. Teluk Kelumpang, Selat Laut, and Selat Sebuku Nature Reserve (Kelautku Natural Reserve) is a representative type of mangrove ecosystems and unique lowland forests that have many species of protected fauna and unique flora of mangrove and lowland forests of South Kalimantan. This area has a distinctive protected flora and fauna of mangroves, for example the proboscis monkey (Nasalis larvatus) which is also an icon animal of South Kalimantan.
Research in this area, especially regarding aquatic fauna and soil and water microorganisms of mangrove forest has not been done. Therefore this research is carried out to generate scientific information on the diversity of aquatic fauna and microorganisms in soil and water of the mangrove ecosystem. This scientific information is very important to be used as a base for further management action. Plankton and benthos data can be used as indicators of water nutrient pollution, because some species of plankton and bethos can only live or abundantly exist in a specific water condition.

\section{MATERIAL AND METHOD}

\section{A. Research Location}

The study was conducted in natural mangrove stands which were in good condition, in the Kelautku Natural Reserve, Kotabaru District, South Kalimantan. Kelautku Natural Reserve is located at coordinates $115^{\circ} 58^{\prime} 10^{\prime \prime}$ $116^{\circ} 24^{\prime} 00^{\prime \prime}$ E, $2^{\circ} 48^{\prime} 10^{\prime \prime}-3^{\circ} 38^{\prime} 50^{\prime \prime} \mathrm{S}$. This area has a flat topography with an elevation of $0-15$ $\mathrm{m}$ above sea level. Soils are alluvial, podzolic and a little muddy on the beach area with sedimentary alluvium rocks and coral reefs. The climate at Kelautku Natural Reserve is of type B (climate type of Schmidt and Ferguson) with an average rainfall of $2,500 \mathrm{~mm} /$ year, average humidity is $70 \%$ and an average temperature of $26^{\circ} \mathrm{C}$. Research location was chosen based on the diversity of mangrove plants where these three locations had a higher number of mangrove species compared to other mangrove forests existing in South Kalimantan. These three locations faced different problems. Conversion of mangrove for palm plantation was the problem in Teluk Kelumpang Natural Reserve area. While in Selat Laut Natural Reserve, some parts of the area were converted to ponds and harbor at nearby settlements. In Selat Sebuku Natural Reserve, mangrove was converted to ponds which were located side by side with the iron mining area (BKSDA Kalimantan Selatan, 2013). 


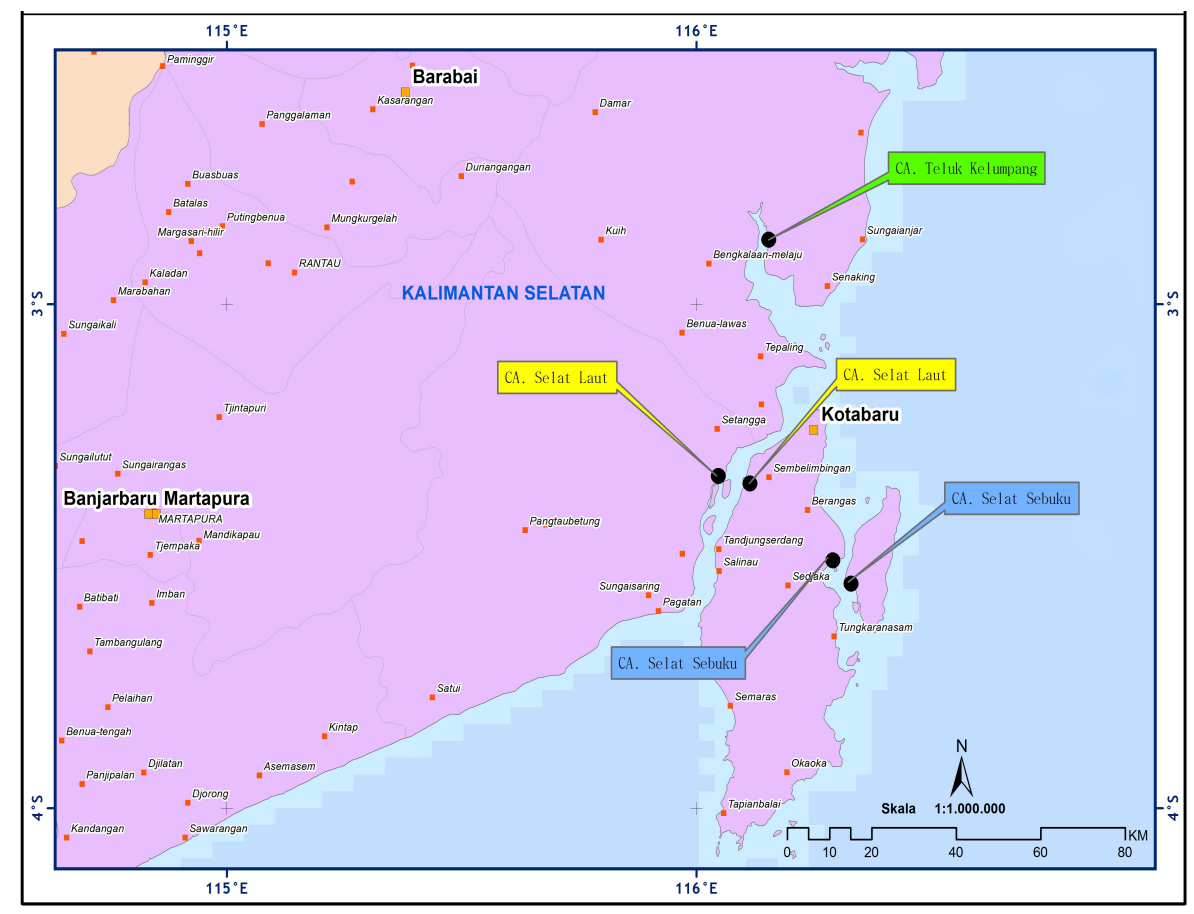

Figure 1. Research site map

\section{B. Experimental Design}

The research activity was carried out through observation/field observations on natural mangrove ecosystem with good conditions in Kelautku Natural Reserve, Kotabaru, South Kalimantan. Parameter observed includes water quality, benthos and plankton.

Water quality in aquatic ecosystems was observed in various parameters such as water temperature, $\mathrm{pH}$, turbidity and salinity. Water temperature, salinity and $\mathrm{pH}$ were measured with a digital tool called conductivity. Its censor part was put into the sea water and soaked for two minutes then the numbers shown were read and recorded. Dissolved oxygen (DO) was measured using Winkler titration method, which was conducted directly in the field.

Turbidity is an optic character of water based on the number of light that was produced and absorbed by the particles in the water. Turbidity is caused by suspended and dissolved organic and inorganic materials. Turbidity influences light penetration into the water thus reduces phytoplankton productivity in the waters (APHA, 1989).
Benthos sampling was carried out on the floor of the mangrove forests using trap method. Trap was made of a plastic tube with holes on both ends with a length of $5 \mathrm{~cm}$. Trap was embedded in the substrate $(5 \mathrm{~cm})$ and then the substrate in the trap was filtered using a sieve of $1 \mathrm{~mm}$ mesh size. Furthermore, the filtered benthos was put in plastic bottles and soaked in a solution of $5 \%$ formalin. Benthos sampling was done three times with three measuring points taken compositely around the river at each location.

Plankton was collected by using plankton net. Microorganisms data were retrieved by taking water samples and analyzed to determine the physical, chemical and laboratory content of microorganism at the Faculty of Fisheries laboratory of Lambung Mangkurat University, Banjarbaru, South Kalimantan. Plankton sampling was done three times with three measuring points taken compositely around river at each location.

Biological Index Analysis was used to determine species diversity level in spesific ecosystem as mentioned by Odum (1994). 


\section{RESULT AND DISCUSSION}

\section{A. Water Quality}

Water quality is the limiting factor for aquatic fauna and microorganisms. Water quality of the three locations is shown below in Table 1.

Temperature range of the three locations is $28-29,4{ }^{\circ} \mathrm{C}$. This range is normal for the tropical area. The difference of the lowest and the highest temperature was not significantly affected by the watershed metabolism (Garno, 2008). Water temperature measured, based on the Decree of Minister of Environment No. 51 year 2004, was within the normal limit, as $28-32^{\circ} \mathrm{C}$ is normal for water temperature in mangrove area.

Generally, sea water has a $\mathrm{pH}$ value above 7 , while suitable $\mathrm{pH}$ value for water life is 7-8.5. The $\mathrm{pH}$ parameter in Selat Laut and Selat Sebuku was in the normal range (7-8.5). While $\mathrm{pH}$ parameter in Teluk Kelumpang location was below the normal limit. Low $\mathrm{pH}$ parameter in Teluk Kelumpang was caused by the dense settlement nearby where disposal of domestic litters mainly detergents resulted in degradation of $\mathrm{pH}$ parameter (Susana, 2009).

Similarly Dissolved Oxygen (DO) in Selat Laut and Selat Sebuku was in normal range, but DO in Teluk Kelumpang was below normal. Salinity of the three locations was within the normal range. The low value of dissolved oxygen was in the same rate as the low value of $\mathrm{pH}$. This has confirmed that these waters had been polluted by domestic litter (Susana, 2009).

\section{B. Benthos}

Benthos found in the research locations are Mollusca and Annelida. Quantity and diversity of benthos are shown in Table 2 .
In general, Table 2 shows the highest quantity of benthos was found in Selat Sebuku Nature Reserve. The lowest quantity of benthos abundance was in Selat Laut Nature Reserve. Shannon Wiener calculation indicated that Selat Sebuku Natural Reserve achieved the highest index of benthos.

The diversity index is affected by water conditions. Teluk Kelumpang and Selat Laut waters have more people accessing the area and fishing vessels than Selat Sebuku, therefore the water pollution in term of waste residues and motorboat fuel are more prevalent in Teluk Kelumpang and Selat Laut. This condition is similar with those stated by Odum (1994), that a healthy water (not contaminated) will show almost a balanced number of individuals of existing species. Otherwise in tainted water, distribution of the number of individuals is uneven and there are spesific species tend to dominate.

In addition, aquatic life can survive if there is a minimum dissolved oxygen of $5 \mathrm{mg} / \mathrm{l}$, and the rest depends on the organism's fitness, degree of activity, the presence of contaminants, temperature, and vice versa (Sastrawijaya, 1991). Dissolved Oxygen (DO) in the waters of Selat Sebuku was higher than those in the other two locations. The DO of Selat Sebuku was about 6.73, while in Teluk Kelumpang and Selat Laut it was 4.13 and 5.53 respectively. The availability of dissolved oxygen was the most possible reason of larger quantity of benthos in the Selat Sebuku than in the other locations.

Eventhough the highest quantity species was recorded at Selat Sebuku Natural Reserve, fellen trees were also found in the area. Local residences mentioned that mangrove trees were

Table 1. Average physical and chemical values of water in Kelautku Natural Reserve

\begin{tabular}{lcccc}
\hline \multicolumn{1}{c}{ Parameter } & T. Kelumpang & S. Laut & S. Sebuku & Mangrove Guide Standard \\
\hline Temperature $\left[{ }^{\circ} \mathrm{C}\right]$ & 28.1 & 29 & 29.43 & $28-32^{\circ} \mathrm{C}$ \\
$\mathrm{pH}$ & 6.75 & 7.16 & 7.13 & $7-8.5$ \\
DO [mg/l] & 4.13 & 5.53 & 6.73 & $>5$ \\
Salinity [\%0] & 21.67 & 24 & 20.67 & $\mathrm{~s} / \mathrm{d} \mathrm{34}$ \\
\hline
\end{tabular}


Table 2. The quantity (individual/1), index of diversity and dominancy of benthos of the three locations in Kelautku Natural Reserve

\begin{tabular}{|c|c|c|c|c|c|}
\hline Phyllum & Class & Genera & $\begin{array}{c}\text { Teluk } \\
\text { Kelumpang }\end{array}$ & $\begin{array}{l}\text { Selat } \\
\text { Laut }\end{array}$ & $\begin{array}{l}\text { Selat } \\
\text { Sebuku }\end{array}$ \\
\hline \multirow[t]{9}{*}{ Mollusca } & Bivalvia & Tellina sp. & 58.7 & 29.3 & 58.7 \\
\hline & Bivalvia & Donax & 56.7 & 14.7 & - \\
\hline & Gastropoda & Terebralia sp. & - & - & 14.7 \\
\hline & Gastropoda & Ceritium & - & - & 14.7 \\
\hline & Bivalvia & Piniidae & - & - & 58.7 \\
\hline & Bivalvia & Mactidae & - & - & 220 \\
\hline & Bivalvia & Anadara granosa & - & - & 234.7 \\
\hline & Gastropoda & Bullidae & - & - & 73.3 \\
\hline & Gastropoda & Nerita & - & - & 14.7 \\
\hline \multirow[t]{4}{*}{ Annelida } & & Diplogasterodae & 14.7 & 29.3 & - \\
\hline & \multicolumn{2}{|c|}{ Abundance [individual/1] } & 132 & 73.3 & 689 \\
\hline & \multicolumn{2}{|c|}{ Diversity index (Shannon Wiener) } & 0.79 & 0,69 & 0.89 \\
\hline & \multicolumn{2}{|c|}{ Dominancy } & 0.48 & 0.66 & 0.46 \\
\hline
\end{tabular}

cut down to build the foundation of bagang (a hut in the sea for fishing). It Was predicted that the utilization of mangrove trees for bagang will damage the mangrove ecosystem.

One of benthos found in Selat Sebuku is Anadara granosa. Which is a bivalvae mollusca in the family of Arcidae, subfamily Anadarinae. Since A. granosa is a filter, feeding organism contamination of the highly productive mudflats with heavy metals tend to be accumulated in their body tissues. This could serve as an important environmental sink of heavy metals and provide an indication of river pollution (Alkarkhi, Ismail, \& Easa, 2008). The quantity high of Anadara granosa indicates the concentration of organic matter in Selat Sebuku water is higher than the other two locations (Prasojo, 2012). Accumulated organic matter was considered coming from residues of illegal ponds activities in Selat Sebuku. The statistic of the Natural Resource Conservation Agency of South Kalimantan (2013) stated that 2,346 ha of illegal ponds existed in Selat Sebuku Natural Reserve. Besides that, the location of
Selat Sebuku Natural Reserve was nearby iron mining. Anadara granosa is one of the food sources for fishermen which is high in protein. In addition, Anadara granosa (blood clams) is also an indicator of water condition due to its ability to accumulate the metal better than other aquatic animals because it settle and filter food (filter feeders) and moves slow to be able to escape the effects of pollution (Fauziah, 2012).

\section{Plankton}

1. Phytoplankton

In contrary to the abundance of benthos, the quantity of phytoplankton in Selat Sebuku showed the smallest value compared to the other two locations. It is probably caused by the smaller number of activities and fewer settlements compared to the other locations. In addition, the higher exposure to sea waves also caused lower abundance of phytoplankton in Selat Sebuku. Phytoplankton condition in research location can be seen in Table 3 .

Lee (1978) in Zulkifli (2009) stated that if the water a diversity index value is smaller than 
1 , then the water is categorized as polluted. If the diversity index ranges from 1.5 to 2.0 then the water is in the lightly polluted category, and if it has diversity index of more than 2.0, then the water is categorized as not polluted. Diversity index in these three waters were more than 2 , therefore the waters were not polluted.

The quality area of phytoplankton in Teluk Kelumpang was the highest compared to the other two locations. Teluk Kelumpang has the lowest level of turbidity compared to the other two locations. A condition of clear water allows better sunlight penetration, thus supporting the development and activity of phytoplankton photosynthesis. Another possible cause of the abundance of phytoplankton in Teluk Kelumpang and Selat Laut was the content of organic matter in the waste from settlement as nutrient inputs for phytoplankton. The settlements in Teluk Kelumpang and Selat Laut were denser than in Selat Sebuku. This was confirmed with a research of Barus, Sinaga, \& Tarigan (2008) who stated that waters with settlements contributed to phytoplankton abundance by pollutants from domestic activities.

In Teluk Kelumpang and Selat Laut, it was found Cyanophyta, and was not in the waters of Selat Sebuku. Some Cyanophyta can bind nitrogen and act as pioneer plant in nutrient-poor areas such as sandy beaches. Cyanophyta's body is gas vacuoles that can float near the surface of the water, which has a high light intensity. Cyanophyta needs sunlight for photosynthesis. Selat Sebuku has a relatively dense mangrove stand, so that less sunlight reach the waters. Teluk Kelumpang and Selat Laut which more open sea. This was the cause of not finding Cyanophyta in Selat Sebuku. Cyanophyta is usually found in water polluted by phosphor and nitrogen nutrient. The existence of Cyanophyta confirmed the conclusion that the water was in eutrophic condition where Cyanophyta thrived by its adaptation ability to a high oxygen dissolved fluctuation (Garno, 2005).

Cyanophyta found in Teluk Kelumpang and
Selat Laut was from the genera of Oscillatoria that showed that this species had a high tolerance to environment condition (Zulkifli, Husnah, Ridho, \& Juanda, 2009). Bacillariophyceae in both locations tended to be more abundant than in Selat Sebuku. Bacillariophyceae group is a phytoplankton which is commonly found in Indonesian waters because of its ability to cope with extreme environmental conditions and high reproduction capability (Zulkifli et al., 2009; Nurfadillah, Damar, \& Adiwilaga, 2012; Radiarta, 2013; Yuliana, Adiwilaga, Harris, \& Pratiwi, 2012; Thoha \& Amri, 2011). Basillariophyceae class is a diatom that is often found in Indonesian waters, such as Selat Alas, Sumbawa, NTB (Radiarta, 2013). Oscillatoria genus can be used as water bio-indicator to show that the water is moderately polluted (Zulkifli et al., 2009).

Chaetocerros was found in all three locations. Chaetocerros is a species that commonly found in tropical waters (Usman, Kusen, \& Rimper, 2013; Sutomo, 2013; Sawestri \& Farid, 2012; Samsidar, Kasim, \& Salwiyah, 2013; Nurfadillah et al., 2012; Radiarta, 2013; Thoha \& Amri, 2011). In the three locations, Nitachia sp. was found at different rate of quantity. The highest was in two locations Teluk Kelumpang with 150 individuals/1 and Selat Laut with 136.7 individuals/1. In Selat Sebuku it was only 10 individuals/l. Nitzchia is one of the species that will endanger other organisms if it exists in a high number (Garno, 2008).

\section{Zooplankton}

The quantity of zooplankton in Selat Sebuku showed the lowest value. Diversity of zooplankton is illustrated in Table 4. Selat Sebuku had the lowest zooplankton abundance compared to the other two locations. This was related to the number of existing phytoplankton in the water at this location. The high density of zooplankton is affected by high phytoplankton. Phytoplankton abundance in Selat Sebuku was low, so zooplankton abundance was low as well. Zooplankton abundance can be affected by several factors such as the abundance of 
Table 3. Abundance (individual/1), index of diversity and dominancy of Phytoplankton at three locations in Kelautku Natural Reserve.

\begin{tabular}{|c|c|c|c|c|}
\hline Phyllum & Genera & Teluk Kelumpang & Selat Laut & Selat Sebuku \\
\hline Cyanophyta & Oscillatoria & 63.3 & 56.7 & - \\
\hline \multirow[t]{12}{*}{ Chlorophyta } & Closterium & 16.7 & 10 & 26.7 \\
\hline & Meugeotia & 56.7 & 26.7 & - \\
\hline & Gonatozygon & 23.3 & 30 & - \\
\hline & Steletonema & 33.3 & 23.3 & - \\
\hline & Spirogyra & - & - & 6.67 \\
\hline & Cosmocladium & - & - & 93.3 \\
\hline & Cosmarium & - & - & 16.7 \\
\hline & Staurastrum & - & - & 60 \\
\hline & Eunotia & - & - & 40 \\
\hline & Eunotia & - & - & 30 \\
\hline & Pediastrum & - & - & 83.3 \\
\hline & Docidium & - & - & 13.3 \\
\hline \multirow{11}{*}{ Chrysophyta } & Campylodiscus & - & - & 6.67 \\
\hline & Coscinosira & 40 & - & - \\
\hline & Cyclotella & 16.7 & - & 6.7 \\
\hline & Frustulia & 13.3 & - & - \\
\hline & Gomphonema & - & - & 13.3 \\
\hline & Gyrosigma & 156.7 & 116.7 & 110 \\
\hline & Laundria & 96.7 & 73.3 & - \\
\hline & Rhabdonella & - & - & 6.7 \\
\hline & Stephanodiscus & 66.7 & 66.7 & 283.3 \\
\hline & Stephanopyxis & 350 & 300 & - \\
\hline & Streptotheca & 60 & 46.7 & 3.3 \\
\hline \multirow[t]{16}{*}{ Bacillariophyceae } & Bacteriastrum & 216.7 & 193.3 & - \\
\hline & Chaetoceros & 330 & 160 & 53.3 \\
\hline & Coscinodiscus & 53,3 & 50 & - \\
\hline & Nitszchia & 150 & 136.67 & 10 \\
\hline & Rhizosolenia & 66.7 & 66.7 & 16.7 \\
\hline & Thallasiothrix & 220 & 216.7 & 3.3 \\
\hline & Dytillium & 20 & 30 & - \\
\hline & Triceratium & - & - & 6.7 \\
\hline & Melosira & 26.7 & 23.3 & - \\
\hline & Thallasiosira & 56.7 & 40 & - \\
\hline & Surirella & 23.3 & - & - \\
\hline & Diplnoeis & 6.67 & - & - \\
\hline & Diatoma & 83.3 & 43.3 & 16.7 \\
\hline & Biddhulpia & 63.3 & 60 & - \\
\hline & Amphora & 20 & & 13.3 \\
\hline & Hemialus & 16.7 & 20 & - \\
\hline \multicolumn{2}{|c|}{ Abundance [individual/1]) } & 2346.7 & 1813.3 & 976.7 \\
\hline \multicolumn{2}{|c|}{ Diversity index (Shannon Wiener) } & 2.7 & 2,7 & 2 \\
\hline \multicolumn{2}{|l|}{ Dominancy index } & 0.1 & 0.1 & 0.2 \\
\hline
\end{tabular}

phytoplankton, waves and predators (Nybakken, 1988).

At Selat Sebuku, only protozoa zooplankton was discovered, while in Teluk Kelumpang and Selat Laut also zooplankton of phylum crustaceans can be found. Crustascea found in Teluk Kelumpang and Selat laut were from the genera Diaphanosoma, Nauplius, and Diaptomus. The relationship between life expectancy and water temperature of Diaphanosoma dubium Manuilova was in the form of a parabola (Han, Juan, Xian, \& Dumont, 
Table 4. Abundance (individual/l), index of diversity and dominancy of Zooplankton at three locations in Kelautku Natural Reserve

\begin{tabular}{llccc}
\hline \multicolumn{1}{c}{ Phyllum } & \multicolumn{1}{c}{ Genera } & Teluk Kelumpang & Selat Laut & Selat Sebuku \\
\hline Protozoa & Tintinnopsis & 23.3 & 23.3 & - \\
& Peridinium & 6.7 & - & - \\
& Difflugia & 6.7 & - & - \\
& Parafavella & - & - & 6.7 \\
& Peridinium & - & - & 6.7 \\
Crustacea & Gymnodinium & - & - & 3.3 \\
& Diaphanosoma & 10 & 10 & - \\
& Nauplius & 66.7 & 66.7 & - \\
\hline Abundance [individual/1] & Diaptomus & 23.3 & 43.3 & - \\
Diversity index (Shannon Wiener) & 136.7 & 143.3 & 16.7 \\
Evenness index & & 1.4 & 1,1 & 0 \\
Dominancy index & & 0.8 & 0.9 & 0 \\
\hline
\end{tabular}

2011). It can be said that Diaphanosoma does not like too high temperatures. Among the three study sites, Selat Sebuku has the highest water temperature $\left(29.43^{\circ} \mathrm{C}\right)$.

\section{CONCLUSION}

Research the study shows that the quality of mangrove waters, directly or indirectly, was mostly affected by human activities such as settlements, mangrove conversion to ponds, agriculture, harbor and mining. Some areas of mangrove in Selat Sebuku Natural Reserve had been converted to ponds. Benthos at Selat Sebuku Natural Reserve has the highest diversity index. Anadara granosa is one of the common benthos found in Selat Sebuku. Contrary to the abundance of benthos, the abundance of phytoplankton in the Selat Sebuku showed the smallest value compared to the other two locations, due to many settlements at the two other locations and also it is suspected that Selat Sebuku has a relatively bigger wave exposure than the two other locations. In Teluk Kelumpang Natural Reserve, part of mangrove forest had been converted to ponds and angriculture activities. In Selat Laut Natural Reserve, mangrove forest was converted to ponds, settlements and mining harbor. In addition, input of organic matters from the settlements in Teluk Kelumpang and Selat Laut also affected the growth of phytoplankton. Cyanophyta found in Teluk Kelumpang and Selat Laut was from the genera of Oscillatoria that showed that this species had a high tolerance to environment condition. Good condition of mangrove will support a good aquatic environment condition as well. Mangrove protected area manager need to conserve mangrove and prevent mangrove conversion to other land uses. Beside that, routine control of mangrove water and surrounding areas is needed.

\section{ACKNOWLEDGEMENT}

A big thank to the Head of Banjarbaru Forestry Research Institute that facilitated this research. We also thank to our technicians Hendra Ambo Basiang and Arif Susianto who helped us doing the field work.

\section{REFERENCES}

Alkarhi, F. M. A., Ismail, N., \& Easa, A. M. (2008). Assessment of arsenic and heavy metal contents in cockles (Anadara granosa) using multivariate statistical techniques. Journal of Hazardous Materials, 150(3), 783-789. 
American Public Health Association. (1989). Standard methods for the examination of water and waste water including bottom sediment and sludges. New York: Amer. Publ. Health Associacion Inc.

Ananda, K., Sridhar, K. R., Raviraja, N. S., \& Barlocher, F. (2008). Breakdown of fresh and Dried Rhizophora mucronata leaves in a Mangove of Southest India. Wetlands Ecology and Management, 16(1), 1-9. doi:Doi 10.1007/ s11273-007-9041-y.

Balai Konservasi Sumberdaya Alam Kalimantan Selatan. (2013). Statistics 2012 Balai KSDA South Kalimantan (in Bahasa Indonesia). Kementerian Kehutanan Direktorat Jenderal Perlindungan Hutan dan Konservasi Alam.

Barus, T. A., Sinaga, S. S., \& Tarigan, R. (2008). Phytoplankton primary productivity in relation to physical - chemical water factor in the waters Parapat Lake Toba (in Bahasa Indonesia). Jurnal Biologi Sumatera, (Januari), 11-16.

Domingues, R. B., Barbosam, A., \&Galvao, H. (2008). Constraints on the use of phytoplankton as a biological quality element within the water framework Directive in Portuguese waters. Marine Pollution Bulletin, 56(8), 1389-95. doi:10.1016/j.marpolbul.2008.05.006. Epub 2008 Jun 26.

Fauziah, A. R., Rahardja, B., \& Cahyoko, S. Y. (2012). Correlations of size and concentrations of Heavy Metal Mercury (Hg) of blood cockle (Anadara granosa) on Ketingan Inlet, Sidoarjo, East Java (in Bahasa Indonesia). Journal of Marine and Coastal Science, 1(1), $34-44$.

Garno, Y. S. (2005). Study of water quality status in Jangari Cirata and their eligibility for the water-based recreation and tourism (in Bahasa Indonesia). J. Tek. Ling., 6(2), 424-431.

Garno, Y. S. (2008). Water quality and phytoplankton dynamic at Harapan island waters. J Hidrosfir Indonesia, 3(2), 87-94.

Giesen, W., Wulffraat, S., Zieren, M., \& Scholtren, L. (2006). Mangrove guide book for Southeast Asia. Bangkok: Food and Agriculture Organization (FAO) of the United Nations/Wetland International Dharmasarn Co., Ltd.

Han, B. P., Juan, Y., Xian, L., \& Dumont, Henri, J. (2011). Why is Diaphanosoma (Crustacea: Ctenopoda) so common in the tropics? Influence of temperature and food on the population parameters of Diaphanosoma dubium, and a hypothesis on the nature of tropical cladocerans. Hydrobiologia, 668(1), 109.
Lewandowska, A. M., Hilldebrand, H., Lengfellner, K., \& Sommer, U. (2014). Temperature effects on phytoplankton diversity-The zooplankton link. Journal of Sea Research, 85, 359-364.

Nurfadillah, A., Damar, E., \& Adiwilaga, M. (2012). Phytoplankton communities in the Lake Laut Tawar Central Aceh District, Aceh Province (in Bahasa Indonesia). Depik, 1(2), 93-98.

Nybakken, J. W. (1988). Marine Biology: An ecological approach. Jakarta: PT. Gramedia.

Odum, E. P. (1994). Fundamentals of Ecology. Yogyakarta.: Gadjah Mada University Press.

Radiarta, I. N. (2013). Relationship between phytoplankton distribution with water quality in the Strait Alas, Sumbawa, West Nusa Tenggara (in Bahasa Indonesia). Jurnal Bumi Lestari, 13(2), 234-243.

Samsidar, Kasim, M., \& Salwiyah. (2013). Community structure and distribution of phytoplankton in Rawa Aopa, Angata Konawe Sub District, South Konawe District (in Bahasa Indonesia). Jurnal Mina Laut Indonesia, 2(6), 109-119.

Sari, R. M., Ngabekti, S., \& Martin, F. P. (2013). Phytoplankton diversity in the flow of hot springs Condrodimuko Gedongsongo Semarang District (in Bahasa Indonesia). Journal of Life Science, 2(1), 9-15.

Sawetri, S., \& Farid, A. (2012). Impact assessment of nuclear power plant on the profusion of plankton organisms (in Bahasa Indonesia). In Prosiding Seminar Nasional Pengembangan Energi Nuklir V. Jakarta: Pusat Pengembangan Energi Nuklir, Badan Tenaga Nuklir Nasional.

Susana, T. (2009). The acidity level $(\mathrm{pH})$ and dissolved oxygen as indicators of water quality in Cisadane River Inlet (in Bahasa Indonesia). Jurnal Teknologi Lingkungan, 5(2), 33-39.

Sutomo. (2013). Phytoplankton community structure in the gulf of Sekotong and Kodek waters, Lombok District (in Bahasa Indonesia). Jurnal Ilmu dan Teknologi Kelautan Tropis, 5(1), 131-144.

Thoha, H., \& Amri, K. (2011). The composition and profusion of phytoplankton in South Kalimantan waters (in Bahasa Indonesia). Oseanologi dan Limnologi di Indonesia, 37(2), 371-382.

Usman, M. S., Kusen, J. D., \& Rimper, J. R. T. S. L. (2013). The community structure of plankton in Bangka Island waters, North Minahasa District (in Bahasa Indonesia). Jurnal Pesisir dan Laut Tropis, 2(1), 51-57.

Yuliana, Adiwilaga, E. M., Harris, E., \& Pratiwi, N. T. . (2012). The relationship between the profusion of phytoplankton and the 
parameter of physical-chemical waters in the Gulf of Jakarta (in Bahasa Indonesia). Jurnal Akuatika, 3(2), 169-179.

Zulkifli, H., Husnah, Ridho, R. M., \& Juanda, S.
(2009). The quality status of Musi river downstream by examining phytoplankton communities (in Bahasa Indonesia). Berk. Penel. Hayati, 15, 5-9. 